\title{
Energy Efficient Phosphorus Recovery by Microbial Electrolysis Cell Induced Calcium Phosphate Precipitation
}

\author{
Yang Lei, ${ }^{\dagger, \ddagger \odot}$ Mengyi Du, ${ }^{\dagger}$ Philipp Kuntke, ${ }^{\dagger}$ Michel Saakes, ${ }^{\dagger}$ Renata van der Weijden, ${ }^{*},{ }^{\dagger}$, \\ and Cees J. N. Buisman ${ }^{\dagger,+}$
}

\begin{abstract}
${ }^{\dagger}$ Wetsus, Centre of Excellence for Sustainable Water Technology, P.O. Box 1113, 8900CC Leeuwarden, The Netherlands
${ }^{\ddagger}$ Department of Environmental Technology, Wageningen University and Research, P.O. Box 17, 6700AA Wageningen, The Netherlands
\end{abstract}

\section{Supporting Information}

ABSTRACT: Phosphorus (P) removal and recovery from waste streams is essential for a sustainable world. Here, we updated a previously developed abiotic electrochemical $\mathrm{P}$ recovery system to a bioelectrochemical system. The anode was inoculated with electroactive bacteria (electricigens) which are capable of oxidizing soluble organic substrates and releasing electrons. These electrons are then used for the reduction of water at the cathode, resulting in an increase of $\mathrm{pH}$ close to the cathode. Hence, phosphate can be removed with coexisting calcium ions as calcium phosphate at the surface of the cathode with a much lower energy input. Depending on the available substrate (sodium acetate) concentration, an average current density from $1.1 \pm 0.1$ to $6.6 \pm 0.4 \mathrm{~A} / \mathrm{m}^{2}$ was achieved. This resulted in a $\mathrm{P}$ removal of $20.1 \pm 1.5 \%$ to $73.9 \pm 3.7 \%$, a Ca removal of $10.5 \pm 0.6 \%$ to $44.3 \pm 1.7 \%$ and a $\mathrm{Mg}$ removal of $2.7 \pm 1.9 \%$ to $16.3 \pm$ $3.0 \%$. The specific energy consumption and the purity of the solids were limited by the relative low $\mathrm{P}$ concentration $(0.23 \mathrm{mM})$ in the domestic wastewater. The relative abundance of calcium phosphate in the recovered product increased from $23 \%$ to $66 \%$ and the energy consumption for recovery was decreased from $224 \pm 7 \mathrm{kWh} / \mathrm{kg} \mathrm{P}$ to just $56 \pm 6 \mathrm{kWh} / \mathrm{kg} \mathrm{P}$ when treating wastewater with higher $\mathrm{P}$ concentration $(0.76 \mathrm{mM})$. An even lower energy demand of $21 \pm 2 \mathrm{kWh} / \mathrm{kg} \mathrm{P}$ was obtained with a platinized cathode.

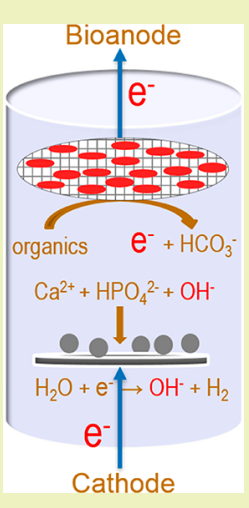
This highlights the promising potential of bioelectrochemical P recovery from P-rich waste streams.

KEYWORDS: bioelectrochemical, phosphate removal, local high $\mathrm{pH}$, amorphous calcium phosphate, energy consumption

\section{INTRODUCTION}

Use of phosphorus fertilizer is crucial for securing food production for the increasing world population. ${ }^{1}$ However, due to the linear flow of phosphorus from ore, fertilizer products to farms, lakes, and many types of waste streams, ${ }^{2}$ there is an increasing concern about the potential shortage of phosphorus resources. ${ }^{1,3}$ At the same time, the discharge of phosphorus containing streams results in the eutrophication of receiving water bodies. ${ }^{2,4}$ This broken cycle of phosphorus calls for phosphorus removal and recovery. ${ }^{4}$ In this context, enhanced biological phosphorus removal, adsorption, and chemical precipitation have emerged as efficient ways for phosphorus removal. ${ }^{3}$ In all processes, insoluble or less-soluble phosphate salts are recovered as the product. Among these phosphate products, calcium phosphate, which is similar in composition to phosphate rock, can be used as a new raw material for the fertilizer industry. ${ }^{5}$

Phosphorus recovery as calcium phosphate has been studied in a large variety of wastewater, but mostly in concentrated phosphorus streams. ${ }^{6-9}$ Few studies deal with wastewater that has a medium or low concentration of phosphorus, for example, domestic wastewater. ${ }^{10}$ We recently showed that during electrochemical treatment, the coexisting cations (i.e., $\mathrm{Ca}^{2+}$ ) and anions (i.e., phosphate) in the domestic wastewater form precipitates on the surface of the cathode, without adding any chemicals to the system. ${ }^{11}$ This provided an excellent way for extracting phosphorus from sewage. Though the concentration of phosphorus in the influent of WWTP is relatively low $\left(5-10 \mathrm{mg} \mathrm{L}^{-1}\right)$, the volume of sewage is huge $(135-150 \mathrm{~L}$ per capital per day), and therefore, phosphorus in domestic wastewater can be an important source for phosphorus recycling. ${ }^{12}$ The added benefits of electrochemical phosphorus recovery are that $\mathrm{COD}$, turbidity, and color of the wastewater were simultaneously reduced as well. The disadvantage, however, is that this process is energy intensive.

In this regard, bioelectrochemical systems appear as promising alternatives for the abiotic electrochemical systems. ${ }^{13}$ In a typical bioelectrochemical system, electroactive microbes grow as firm biofilms on the anode and serve as biocatalysts. ${ }^{13-15}$ Electrons are released during the oxidation of organics by the electroactive bacteria and transferred to the anode. $^{14,15}$ The electrons can be used to reduce water molecules at the cathode, resulting in an increase of local $\mathrm{pH}$ near the cathode surface. ${ }^{16-19}$ It was reported that the $\mathrm{pH}$ in the vicinity of the cathode increases to 10 , while bulk $\mathrm{pH}$ is $7 .^{20}$ Due to the increase of local $\mathrm{pH}$, the soluble calcium phosphate

Received: February 13, 2019

Revised: April 12, 2019

Published: April 18, 2019 


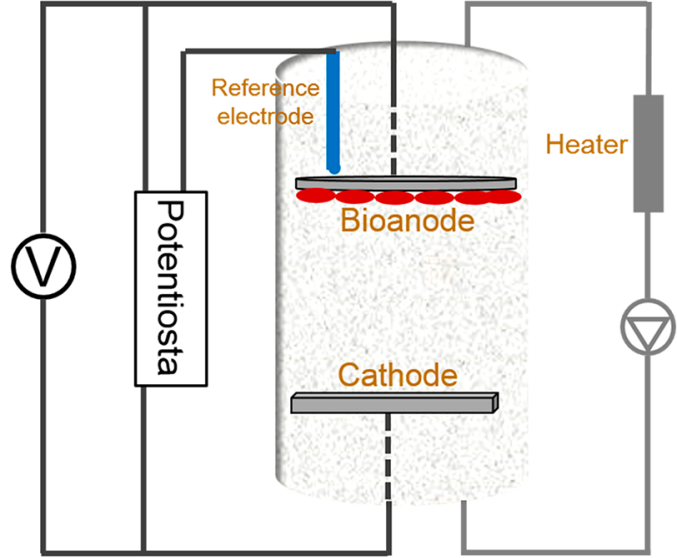

(A)

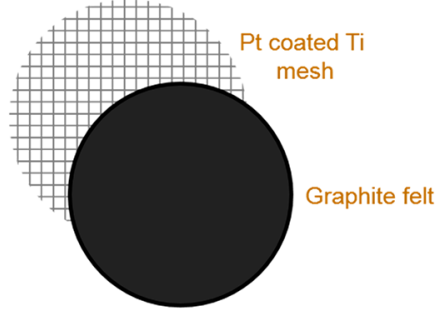

(B)

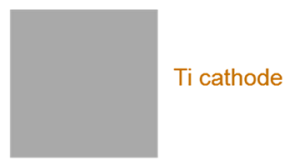

(C)

Figure 1. (A) Configuration of the microbial electrolysis cell, components and the materials of the (B) bioanode and (C) cathode. Both electrodes were welded to (platinum coated) titanium rods for connection. The graphite felt and the platinum-coated titanium mesh were fixed with platinum wire.

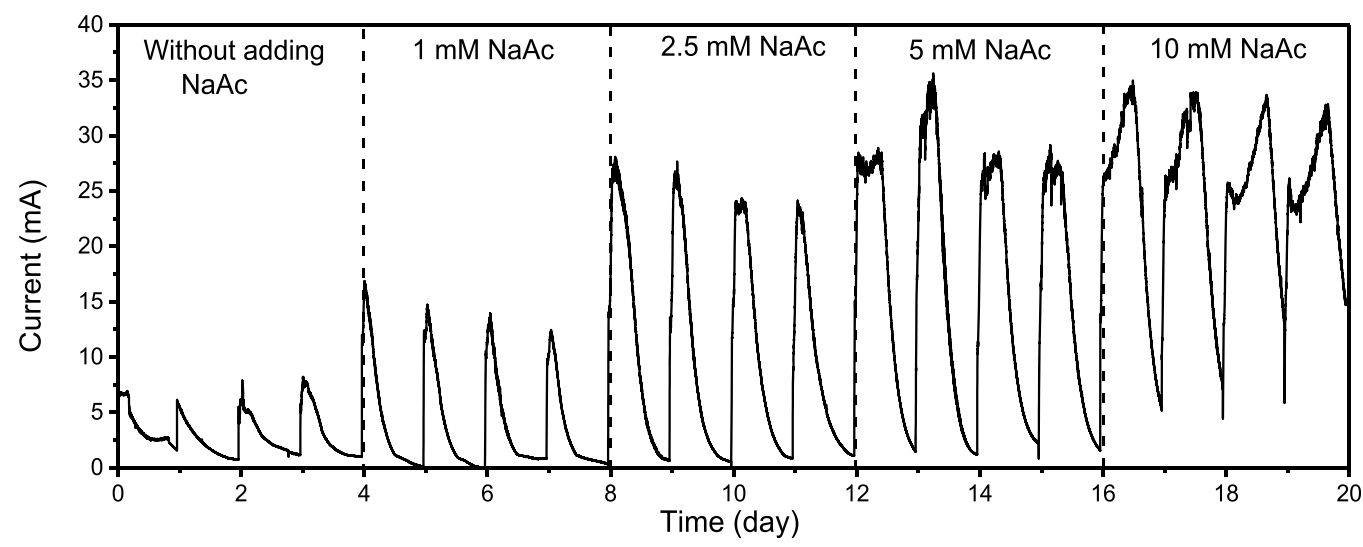

Figure 2. Current production as a function of sodium acetate $(\mathrm{NaAc})$ concentration. Overall, the current curve was reproducible among the four fed batch cycles. Conditions: bioanode potential, $-0.35 \mathrm{~V}$; distance between electrodes, $1 \mathrm{~cm}$; batch cycle time, $24 \mathrm{~h}$.

species becomes supersaturated and forms a solid species on the surface of the cathode, as in abiotic electrochemical systems. $^{11,21}$

The advantages of using a bioanode are substantial. First, the energy needed for electrochemical phosphorus recovery are significantly reduced. ${ }^{16-19,22}$ The oxidation potential for sodium acetate $(\mathrm{NaAc})$, which is a typical substrate used in bioelectrochemical systems, is $-0.278 \mathrm{~V}$ (vs NHE), which is $1.1 \mathrm{~V}$ lower than abiotic water oxidation $(0.817 \mathrm{~V}$, vs NHE), under standard conditions. ${ }^{23}$ The use of a bioanode avoids the formation of chlorine at the anode, which is an issue in abiotic electrochemical systems. ${ }^{24}$ Chlorine, once produced, can result in the formation of chlorinated organic compounds which are extremely toxic. ${ }^{24,25}$

Bioelectrochemical systems have been widely used in wastewater treatment for resource recovery and energy production. $^{13,26-28}$ The early work of Ichihashi and Hirooka ${ }^{16,17}$ and Roland et al. ${ }^{19}$ proved the possibility of bioelectrochemical phosphorus recovery, relying on either artificial wastewater or on concentrated phosphate streams and ion selective membranes. The first simple chamber microbial electrolysis cell (MEC) for phosphorus recovery was developed and tested with artificial wastewater by Roland and Logan. ${ }^{18}$ Yuan and $\mathrm{Kim}^{22}$ extended the application of $\mathrm{MEC}$ in a simple cell with improved cathode configurations, yet still in concentrated solutions. In addition, all the reported studies focused on struvite $\left(\mathrm{MgNH}_{4} \mathrm{PO}_{4} \cdot 6 \mathrm{H}_{2} \mathrm{O}\right)$ as the product. In this context, due to the lack of magnesium $(\mathrm{Mg})$ in the wastewater relative to phosphate and ammonium, ${ }^{29}$ the supply of $\mathrm{Mg}$ source was essential in all these studies. This hinders the further adoption of bioelectrochemical phosphorus recovery, though it shows great potential. We are not aware of any study with MEC focusing at producing calcium phosphate as the recovered product.

Inspired by the successful demonstration of electrochemical phosphorus recovery as calcium phosphate, ${ }^{21,30-32}$ we studied the possibility of energy reduction by upgrading the abiotic electrochemical system to a bioelectrochemical system. This proof of principle, the efficiency of the bioelectrochemical system and its relation to substrate concentration and the composition of recovered products were systematically investigated.

\section{MATERIALS AND METHODS}

Electrodes. The bioanode was made of a platinum-coated (20 g $\left.\mathrm{m}^{-2}\right)$ Ti mesh in the form of a disk $(\mathrm{Pt}-\mathrm{Ti}, 80 \mathrm{~mm} \varnothing)$ and a piece of graphite felt (thickness of $3 \mathrm{~mm}$, FMI Composites Ltd., Galashiels, Scotland) connected to the Pt-Ti disk. We used Pt wire to fix the graphite felt to the mesh $\mathrm{Pt}-\mathrm{Ti}$ disk. On top of the bioanode, a 120 $\mathrm{mm}$ long $\mathrm{Pt}-\mathrm{Ti}$ rod $(3 \mathrm{~mm} \varnothing)$ was welded to the center of the 
bioanode. The cathode was made of a Ti plate (grade one, $6 \times 6 \mathrm{~cm}$ ). The $\mathrm{Pt}-\mathrm{Ti}$ current collector and the $\mathrm{Ti}$ cathode were provided by MAGNETO Special Anodes BV (The Netherlands).

Reactor Design, Start-up, and Operation. The reactor has the same design as the abiotic electrochemical cell that we used previously. ${ }^{31}$ The difference is that we replaced the abiotic anode with a bioanode. Figure 1 illustrates the configuration of the MEC. The MEC is operated in a three-electrode system, with the bioanode as the working electrode and the cathode as the counter electrode. A reference electrode $(\mathrm{Ag} / \mathrm{AgCl}, 0.210 \mathrm{~V}$ vs SHE, QM713X, ProSense B.V.) was placed close to the bioanode. The bioanode potential was controlled at $-0.35 \mathrm{~V}$ by a potentiostat (Vertex, Ivium Technologies, The Netherlands), which is slightly higher than the oxidation potential of $\mathrm{NaAc}(>100 \mathrm{mV}$ overpotential under typical experimental conditions) to provide electroactive bacteria with a competitive advantage over methanogens. ${ }^{33}$ The average overpotential was about $190 \mathrm{mV}$ under the applied condition at the start of the experiments. In this paper, all potentials were reported related to the $\mathrm{Ag} / \mathrm{AgCl}$ reference electrode. The bioanode and the cathode were located on the top and bottom of the electrochemical cell at a distance of $10 \mathrm{~mm}$. The reactor temperature was maintained at $29.5 \pm 0.5{ }^{\circ} \mathrm{C}$ using a thermostat. Initially, the electrochemical cell was inoculated with artificial wastewater, containing $1 \mathrm{~mL} / \mathrm{L}$ trace element solution and the following: $0.82 \mathrm{~g} / \mathrm{L} \mathrm{CH}_{3} \mathrm{COONa}, 0.74 \mathrm{~g} / \mathrm{L} \mathrm{KCl}, 0.58 \mathrm{~g} / \mathrm{L} \mathrm{NaCl}$, $3.4 \mathrm{~g} / \mathrm{L} \quad \mathrm{KH}_{2} \mathrm{PO}_{4}, 4.35 \mathrm{~g} / \mathrm{L} \quad \mathrm{K}_{2} \mathrm{HPO}_{4}, 0.28 \mathrm{~g} / \mathrm{L} \mathrm{NH} \mathrm{NH}_{4} \mathrm{Cl}, 0.1 \mathrm{~g} / \mathrm{L}$ $\mathrm{MgSO}_{4} \cdot 7 \mathrm{H}_{2} \mathrm{O}$, and $0.1 \mathrm{~g} / \mathrm{L} \mathrm{CaCl} \cdot 2 \mathrm{H}_{2} \mathrm{O}$. ${ }^{34}$ The biomass used for inoculation was collected from an active microbial rechargeable battery cell. ${ }^{35}$ The reactor was operated in fed-batch mode with regular replacement of substrate (typically every $24 \mathrm{~h}$ ). The working volume of the bioreactor was $900 \mathrm{~mL}$. The solution in the reactor was mixed by a peristaltic pump at a flow rate of $60 \mathrm{~mL} \mathrm{~min}{ }^{-1}$. After inoculation within 3 days, the system started to produce a positive current. After 2 weeks, the bioanode was completely covered by a visible red biomass. In the meantime, reproducible current was recorded (see Figure 2). Then, experiments with real domestic wastewater (with additional $\mathrm{NaAc}$ ) were performed. The wastewater was sampled from a local wastewater treatment plant (Leeuwarden, The Netherlands). The main composition of the wastewater is shown in Table S1. Each experiment lasted for $24 \mathrm{~h}$. In this period, the current and the cell voltage between the working and the counter electrode were recorded. Liquid samples before and after $24 \mathrm{~h}$ treatment were taken for analysis. In some cases, the time was extended to 48 and $72 \mathrm{~h}$ and samples were also taken. At least four repetitions were performed, and the mean and standard deviation of the collected data are reported.

Analysis. We used ICP-AES (Optima 5300 DV, PerkinElmer) to quantify the concentration of soluble calcium (Ca), phosphorus (P), and magnesium $(\mathrm{Mg})$. We applied the standard cuvette test (LCK114, Hach Company) to measure the concentration of chemical oxygen demand (COD). We quantified the concentrations of cations $\left(\mathrm{Na}^{+}, \mathrm{NH}_{4}^{+}\right)$and anions (chloride, sulfate, nitrate, and nitrite) with ion chromatography (IC, Compact IC 761, Metrohm). We analyzed the total organic carbon and inorganic carbon by a TOC-LCPH analyzer equipped with an ASI-L auto sampler (Shimadzu). Prior to ICP-AES and IC analysis, samples were filtered with $0.45 \mu \mathrm{m}$ membrane filter. The qualification of solid phases was achieved with $\mathrm{X}$-ray Powder Diffraction (XRD, Bruker) using $\mathrm{Cu} \mathrm{K} \alpha$ radiation. Details about the information on XRD can be found in a previous publication. $^{31}$

Calculations. The average produced current and cell voltage in each experiment for different $\mathrm{NaAc}$ concentration was calculated with MATLAB. Prior to the calculations, the curve fitting for both the recorded current and the cell voltage were performed to meet the prerequisite of integral. The MATLAB function "spline" was used to fit the curves and the "integral" function was applied to solve integral through area measurement. The current density $\left(\mathrm{A} \mathrm{m}^{-2}\right)$ was defined by the average current and the projected surface area of the cathode $\left(36 \mathrm{~cm}^{2}\right)$.
The Coulombic efficiency (CE) was defined as the ratio between the produced charge and the theoretical charge released by the oxidation of substrate (eq 1$)$ :

$$
\mathrm{CE}(\%)=100 \times \frac{8 \int \mathrm{Id} t}{F V \Delta \mathrm{COD}}
$$

$I$ is the electric current (A), $F$ is the Faraday constant ( $96485 \mathrm{C}$ $\left.\mathrm{mol}^{-1}\right), V$ is the volume of the reactor $(0.9 \mathrm{~L}), \Delta \operatorname{COD}(\mathrm{g} / \mathrm{L})$ is the removed COD in one fed-batch cycle, and the factor 8 is the quotient from the molecular weight of oxygen $\left(32 \mathrm{~g} \mathrm{~mol}^{-1}\right)$ and amount of electrons transferred per mole of oxygen (4).

The electric energy consumption $\left(W_{\mathrm{E}}\right)$ was calculated by eq 2 :

$$
W_{\mathrm{E}}=\int_{0}^{t} I U \mathrm{~d} t
$$

where $U$ is the recorded cell voltage $(\mathrm{V})$.

The anode overpotential were calculated as the difference between the applied anode potential and the theoretical anode potential $\left(\eta_{\text {anode }}\right.$ $\left.=E_{\text {anode,measured }}-E_{\text {anode,theoretical }}\right) .{ }^{15}$

\section{RESULTS AND DISCUSSION}

Current Production and COD Conversion. Before evaluating the efficiency of bioelectrochemical system, it is necessary to check if the MEC could work properly, which can be evaluated by the produced current. Figure 2 shows the current production in relation to the $\mathrm{NaAc}$ concentration in the MEC. Without adding external substrate, the MEC produces positive current, which suggests that the bioanode can oxidize the organics in the domestic wastewater and produce electricity. The average current in $24 \mathrm{~h}$ produced without adding $\mathrm{NaAc}$ is $3.0 \pm 0.2 \mathrm{~mA}$, corresponding to a current density of $0.84 \pm 0.1 \mathrm{~A} \mathrm{~m}^{-2}$. It should be noted that without adding additional substrate the domestic wastewater should be fresh domestic wastewater. With stored wastewater, the current density recorded was very low. This is because the easily biodegradable COD was consumed by the microbes originating from the wastewater even though we stored the wastewater at a $4{ }^{\circ} \mathrm{C}$ fridge. In Figure $\mathrm{S} 1$, the initial COD decrease over the storage period is shown. Because of this, additional COD (as NaAc) was added at the start of each experiment.

Figure S2 summarizes the removal of COD, current density, and Coulombic efficiency in relation to $\mathrm{NaAc}$ concentration. With $1.0 \mathrm{mM} \mathrm{NaAc}$ added to the stored raw wastewater, the initial COD is $128 \pm 8 \mathrm{mg} \mathrm{L}^{-1}$, and with $10 \mathrm{mM} \mathrm{NaAc}$, the initial COD increases to $640 \pm 34 \mathrm{mg} \mathrm{L}^{-1}$. The removal of COD also increases from $45.7 \pm 3.4 \%$ at $1.0 \mathrm{mM} \mathrm{NaAc}$ to the highest $(79.8 \pm 2.0 \%)$ at $10 \mathrm{mM} \mathrm{NaAc}$. In response to the increased $\mathrm{NaAc}$ dosage and $\mathrm{COD}$ conversion, the current production also increases. As can be seen from Figure 2, the current curve is reproducible for the four tests. At the beginning the current starts to increase immediately after we turn on the potentiostat and the peak current occurs within $1 \mathrm{~h}$ and then starts to slowly decrease, resulting from the decrease of available substrate. With increasing $\mathrm{NaAc}$ concentration, the observed current peak shifts in time, for instance, at a concentration of $10 \mathrm{mM} \mathrm{NaAc}$, the current peak was observed at $12 \mathrm{~h}$. The calculated average current density in $24 \mathrm{~h}$ is $1.1 \pm$ $0.2 \mathrm{~A} \mathrm{~m}^{-2}$ with $1.0 \mathrm{mM} \mathrm{NaAc}$. The value increases to $2.7 \pm 0.3$ with $2.5 \mathrm{mM} \mathrm{NaAc}$ and further to $4.4 \pm 0.2$ with $5.0 \mathrm{mM}$ $\mathrm{NaAc}$, reaching the highest current density of $6.6 \pm 0.4 \mathrm{~A} \mathrm{~m}^{-2}$ at $10 \mathrm{mM} \mathrm{NaAc}$. However, in terms of $\mathrm{CE}$, an overall decreasing trend was observed with increasing $\mathrm{NaAc}$ concentration from $54.7 \pm 12.9 \%$ at $2.5 \mathrm{mM}$ to $36.4 \pm 2.5 \%$ 
at $10 \mathrm{mM}$. Such a trend was seen previously. ${ }^{36}$ There are multiple reasons for the low CE. First of all, the presence of alternative electron acceptors (i.e., sulfate or $\mathrm{O}_{2}$ ) will lower the Coulombic efficiency. Indeed, in the presence of $10 \mathrm{mM} \mathrm{NaAc}$, we found that the sulfate concentration decreased by $62.3 \pm$ $6.3 \%$. This is accompanied by the formation of dark precipitates in the circulation tubes, which may be due to metal sulfide formation. Second, methanogens may compete with the electricigens to produce methane, especially in excess of NaAc. ${ }^{33}$

Bioelectrochemical Phosphorus Removal. Associated with the current production in the MEC, the concentration of soluble phosphorus decreased and the higher the NaAc concentration, the higher the removal of phosphorus $(\mathrm{P})$ and also calcium $(\mathrm{Ca})$ and magnesium $(\mathrm{Mg})$. The $\mathrm{P}$ removal was dependent on the substrate conversion to electricity, since precipitation was induced by the increase of local $\mathrm{pH}$, as we confirmed in the abiotic system. ${ }^{21}$ The reduction of water molecules at the cathode of the MEC, resulting in hydrogen production, led to a local high $\mathrm{pH}$ compared to the bulk solution. We have also seen the increase in $\mathrm{P}$ removal with increasing current density in our previous experiments with the abiotic system. ${ }^{30}$ During experiments with the MEC, the removal efficiency of $\mathrm{P}$ was around $20 \%$ with $1.0 \mathrm{mM} \mathrm{NaAc}$ added (Figure 3). At the same time, 11\% $\mathrm{Ca}$ and $3 \% \mathrm{Mg}$ were

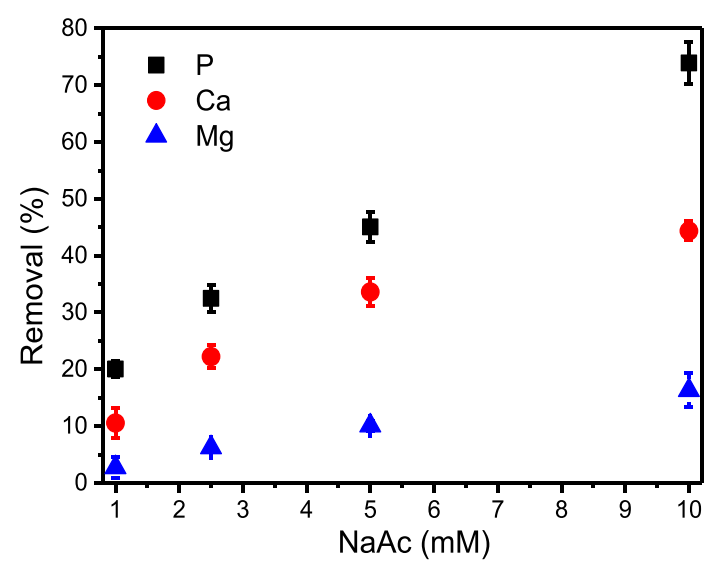

Figure 3. Removal percentage of $\mathrm{Ca}, \mathrm{Mg}$, and $\mathrm{P}$ as a function of the sodium acetate $(\mathrm{NaAc})$ concentration in the microbial electrolysis cell. Conditions: bioanode potential, $-0.35 \mathrm{~V}$; distance between electrodes, $1 \mathrm{~cm}$; microbial electrolysis time, $24 \mathrm{~h}$.

removed. With $2.5 \mathrm{mM} \mathrm{NaAc}$, the $\mathrm{P}$ removal efficiency increased by $12 \%$, which was accompanied by an increase of $10 \%$ for $\mathrm{Ca}$ and $3 \%$ for $\mathrm{Mg}$. Likewise, the removal of $\mathrm{P}, \mathrm{Ca}$, and $\mathrm{Mg}$ increased proportionally with $5.0 \mathrm{mM} \mathrm{NaAc}$. At $10 \mathrm{mM}$ NaAc, nearly $74 \% \mathrm{P}, 44 \% \mathrm{Ca}$, and $16 \% \mathrm{Mg}$ were removed from the wastewater. The $\mathrm{P}$ recovery performance was poor (about 9\%) without adding $\mathrm{NaAc}$, even with fresh wastewater (data not shown). This is because, although the initial total COD of fresh wastewater is $271 \pm 8.6 \mathrm{mg} / \mathrm{L}$, the soluble COD (100 \pm $1.2 \mathrm{mg} / \mathrm{L}$ ) is low. As a result, the average current density generated with fresh wastewater is just $0.84 \pm 0.1 \mathrm{~A} \mathrm{~m}^{-2}$, which is lower than that of adding $1.0 \mathrm{mM} \mathrm{NaAc}(1 \pm 0.2 \mathrm{~A}$ $\left.\mathrm{m}^{-2}\right)$.

In response to the removal of ions in the bulk solution, precipitates were seen on the counter electrode (cathode), as seen in the abiotic electrochemical system. ${ }^{11,21,30}$ The precipitates were characterized with XRD (Figure 4A) to determine the solid phases. For the precipitates formed under different NaAc dosing, all XRD spectra show a good match with calcite $\left(\mathrm{CaCO}_{3}\right)$. This indicates that the precipitates were predominantly $\mathrm{CaCO}_{3}$, while the calcium phosphate was in an amorphous phase. ${ }^{11}$ The removal of $\mathrm{Mg}$ as brucite (Mg$\left.(\mathrm{OH})_{2}\right)$, which could also be formed, is highly dependent on the current density. ${ }^{11}$ At low concentration of $\mathrm{NaAc}$ (1-5 $\mathrm{mM}$ ), the XRD pattern of brucite cannot be identified in the samples taken from the bioelectrochemical system. The removal efficiency of $\mathrm{Mg}$ was just $2.7 \pm 1.9 \%$ with $1 \mathrm{mM}$ $\mathrm{NaAc}\left(1.1 \pm 0.2 \mathrm{~A} \mathrm{~m}^{-2}\right)$. After we increased the dosage of $\mathrm{NaAc}$ to $10 \mathrm{mM}$, the generated current increased, and this resulted in an increase in $\mathrm{Mg}$ removal. Nearly $16 \% \mathrm{Mg}$ was removed in the presence of $10 \mathrm{mM} \mathrm{NaAc}\left(6.6 \pm 0.4 \mathrm{~A} \mathrm{~m}^{-2}\right)$. In this case, typical peaks of brucite at $2 \theta=38^{\circ}$ and $18.6^{\circ}$ were found in the XRD pattern (Figure 4A). To investigate the amorphous calcium phosphate (ACP) content, the precipitates collected in the presence of $10 \mathrm{mM} \mathrm{NaAc}$ were heated at 550 ${ }^{\circ} \mathrm{C}$ for $2 \mathrm{~h}$ and then characterized with XRD. In this way, the organic substances can be removed, and the amorphous phase may recrystallize to a crystalline phase. Indeed, as shown in Figure 4B, the XRD pattern of the heated samples matched with hydroxyapatite (HAP), $\mathrm{MgO}$, and $\mathrm{CaO}$. The XRD characterization of solids before and after heating treatment confirmed the precipitates as a mixture of ACP, calcite, and brucite, which is consistent with the composition of solids recovered in the abiotic electrochemical system. ${ }^{11}$

Based on our previous calculation approach, ${ }^{37}$ we estimated the different quantities of precipitates (Figure 4C) and the relative abundance of the three species in the products (Figure 4D) as a function of $\mathrm{NaAc}$ concentration. The amount of all three species increased with the increase of NaAc concentration. Nonetheless, regardless of the $\mathrm{NaAc}$ dosage, the precipitates consisted of more than $65 \%$ of calcite and the relative abundance of ACP was just around $20 \%$. The low content of ACP is explained by the much lower phosphorus concentration in comparison to bicarbonate, which results in the dominant calcite formation. ${ }^{11}$

Phosphorus Removal in One Fed-Batch Test with Extended Time. In the abiotic system, we saw a clear increase of phosphorus removal efficiency with the increase of electrolysis time. However, in the biotic system, the removal efficiency of phosphorus decreased with extended microbial electrolysis time. In the presence of $10 \mathrm{mM} \mathrm{NaAc}$, the concentration of phosphorus decreased from $7.0 \pm 0.1$ to 1.7 $\pm 0.3 \mathrm{mg} \mathrm{L}^{-1}$ in $24 \mathrm{~h}$ (Figure $5 \mathrm{~A}$ ). Then, the $\mathrm{P}$ concentration increased to $3.6 \pm 0.1 \mathrm{mg} \mathrm{L}^{-1}$ within $48 \mathrm{~h}$ and further increased to $5.6 \pm 0.1 \mathrm{mg} \mathrm{L}^{-1}$ in $72 \mathrm{~h}$. We also observed similar trends for $\mathrm{Ca}$ and $\mathrm{Mg}$, but these were less obvious. This was probably due to the dissolution of initial precipitates, which results in the increase of $\mathrm{P}, \mathrm{Ca}$, and $\mathrm{Mg}$ concentrations in the bulk solution. These changes of ion concentration in the wastewater were connected to the depletion of COD in the wastewater and the associated decrease in current density during operation of the bioelectrochemical system over the 3 day experimental period. The COD decreased from $622 \pm 20$ to $121 \pm 12 \mathrm{mg} \mathrm{L}^{-1}$ within $24 \mathrm{~h}$ (Figure $5 \mathrm{~A}$ ). Due to the degradation of COD, the output current of the MEC decreased significantly (Figure 5B). While the average current on the first day was $23.3 \pm 2.0 \mathrm{~mA}\left(6.5 \pm 0.5 \mathrm{~A} \mathrm{~m}^{-2}\right)$, the average current in the second day and the third day were just $2.6 \pm 0.3 \mathrm{~mA}$ $\left(0.71 \pm 0.07 \mathrm{~A} \mathrm{~m}^{-2}\right)$ and $1.0 \pm 0.1 \mathrm{~mA}\left(0.26 \pm 0.04 \mathrm{~A} \mathrm{~m}^{-2}\right)$. The precipitation of calcium phosphate and other solid species 

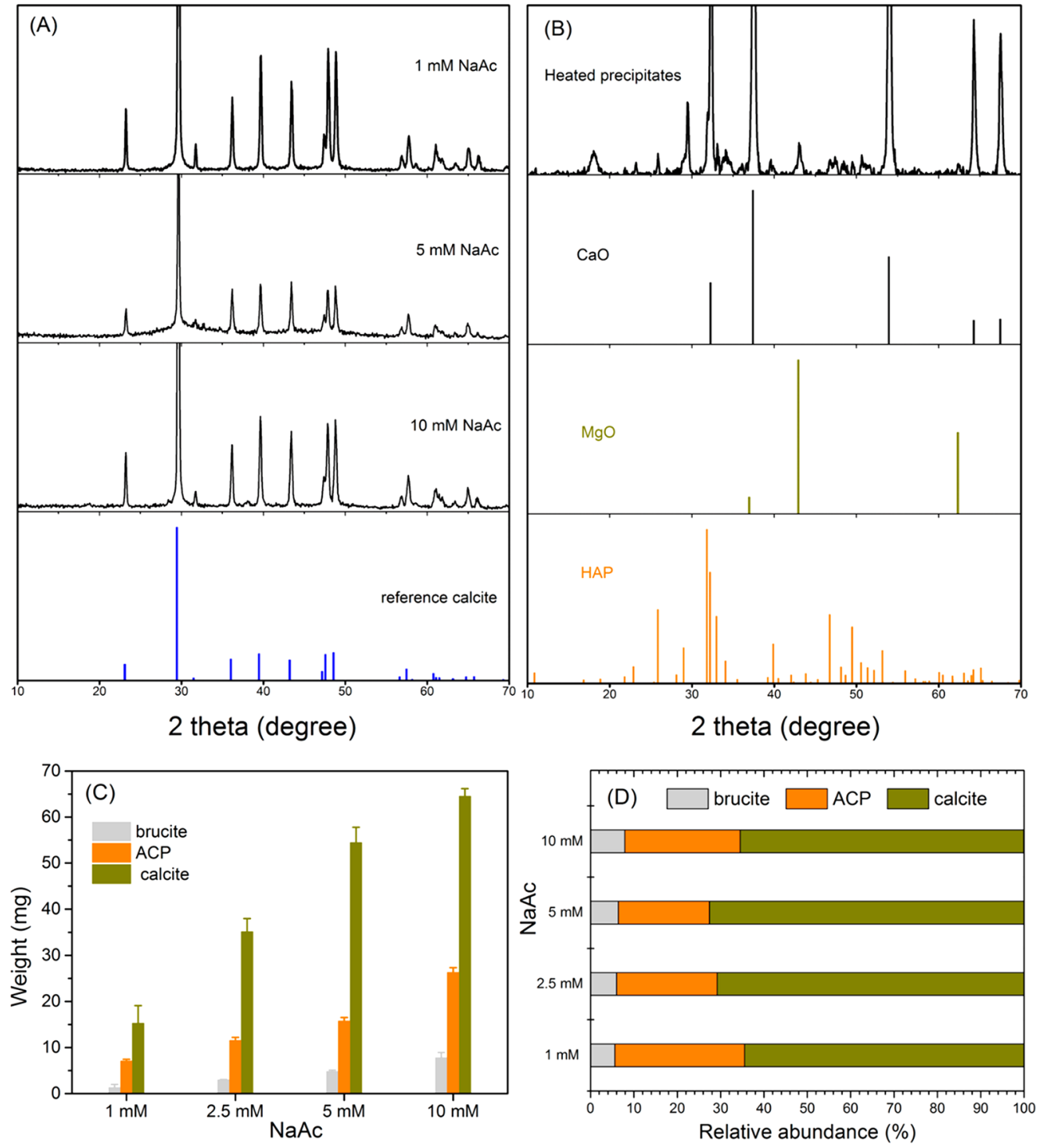

Figure 4. (A) XRD pattern of solids collected in the presence of different sodium acetate (NaAc) concentration, (B) XRD pattern of selected samples after heating treatment, the heated samples were collected in the presence of $10 \mathrm{mM} \mathrm{NaAc},(\mathrm{C})$ amount and (D) the relative abundance of brucite $\left(\mathrm{Mg}(\mathrm{OH})_{2}\right)$, amorphous calcium phosphate $(\mathrm{ACP})$, and calcite $\left(\mathrm{CaCO}_{3}\right)$.
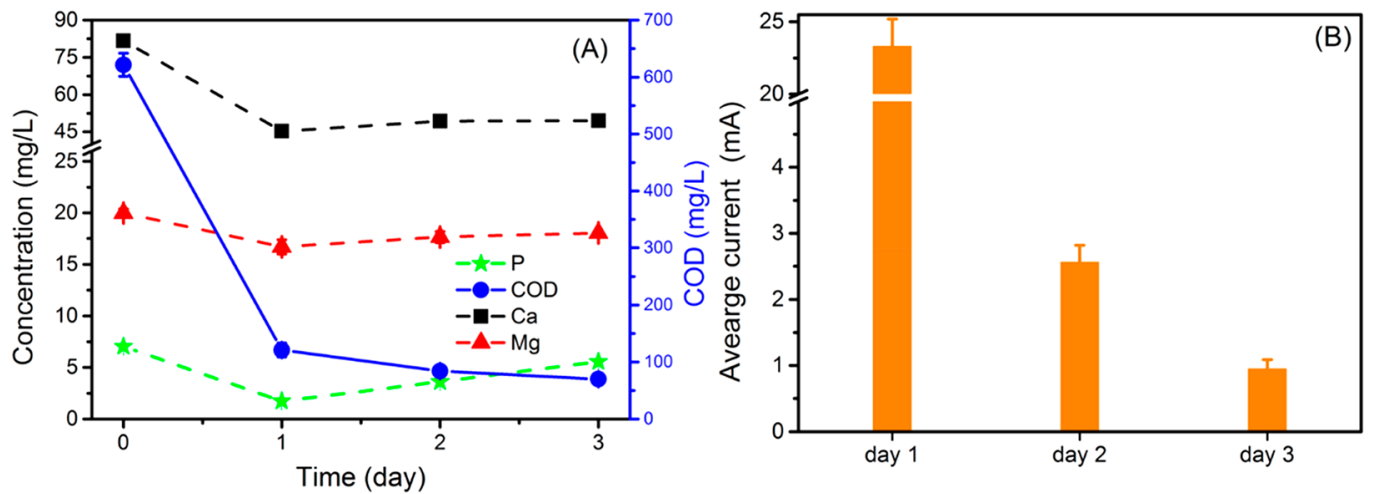

Figure 5. (A) Concentrations of $\mathrm{Ca}, \mathrm{P}, \mathrm{Mg}$, and $\mathrm{COD}$ in the wastewater and (B) the average current each day over a three-day batch test. Conditions: $10 \mathrm{mM} \mathrm{NaAc}$; bioanode potential, $-0.35 \mathrm{~V}$; distance between electrodes, $1 \mathrm{~cm}$.

on the cathode surface is induced by the local high $\mathrm{pH}$ resulting from the (microbial) electrolysis process. Therefore, when the available organic substances were depleted by the electroactive bacteria, the microbial electrolysis process will come to a halt. As a result, the local high $\mathrm{pH}$ cannot be maintained. Therefore, the precipitates will dissolve, accompanied by the increase of ion concentration in the bulk solution. We previously tested the dissolution of precipitates in 
Table 1. Comparison of COD Conversion, Ions Removal, and Current Density in Low and High Phosphorus Concentration

\begin{tabular}{|c|c|c|c|c|c|c|}
\hline \multicolumn{3}{|c|}{ concentration (mM) } & \multicolumn{3}{|c|}{ removal (\%) } & \multirow[b]{2}{*}{ avg current density $\left(\mathrm{A} / \mathrm{m}^{2}\right)$} \\
\hline phosphorus & $\mathrm{NaAc}$ & COD & $\mathrm{Ca}$ & $\mathrm{Mg}$ & $\mathrm{P}$ & \\
\hline 0.23 & 5 & $74.8 \pm 2.8$ & $33.6 \pm 2.4$ & $10.1 \pm 0.9$ & $45.1 \pm 2.7$ & $4.4 \pm 0.2$ \\
\hline 0.76 & 5 & $74.9 \pm 1.5$ & $31.9 \pm 1.3$ & $16.2 \pm 1.3$ & $43.8 \pm 1.3$ & $4.0 \pm 0.2$ \\
\hline
\end{tabular}

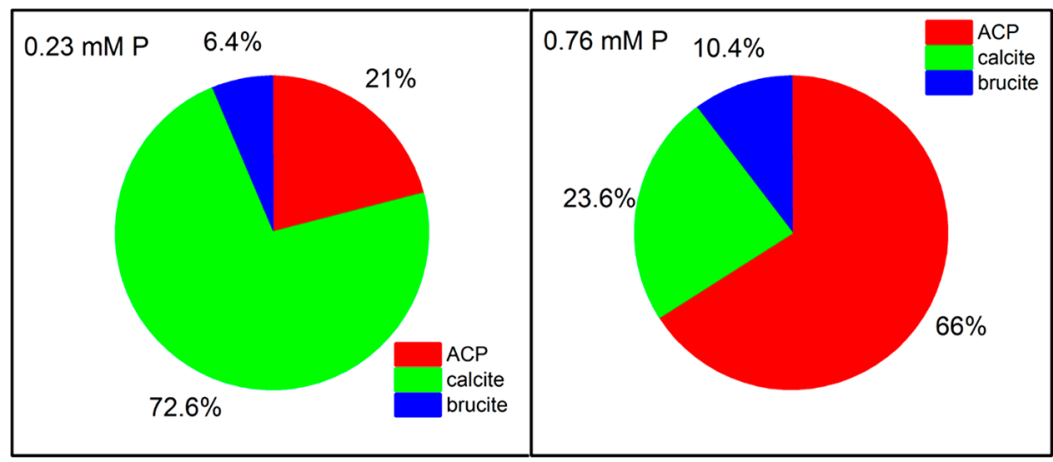

Figure 6. Relative abundance of calcite, brucite, and amorphous calcium phosphate (ACP) in the presence of 0.23 and $0.76 \mathrm{mM}$ phosphorus.

open circuit in abiotic systems. ${ }^{37}$ It was found that only when the bulk solution $\mathrm{pH}$ was acidic, the initial precipitates dissolve. Under alkaline conditions, the precipitates did not dissolve. We measured the bulk solution $\mathrm{pH}$ after 24,48 , and $72 \mathrm{~h}$, which are $7.7,8.1$, and 8.0, respectively. Overall, the bulk solution $\mathrm{pH}$ in the MEC was quite stable. This was due to the presence of bicarbonate, which acts as a buffer in the wastewater. In addition, the degradation of $\mathrm{NaAc}$ also results in the formation of bicarbonate (eq 3).

$$
\mathrm{CH}_{3} \mathrm{COO}^{-}+4 \mathrm{H}_{2} \mathrm{O} \rightarrow 2 \mathrm{HCO}_{3}^{-}+9 \mathrm{H}^{+}+8 \mathrm{e}^{-}
$$

From the point of bulk solution $\mathrm{pH}$, the precipitates should not dissolve. The different behaviors of solids in the abiotic system and the biotic system may be explained in several ways. First of all, though the precipitates are a mixture of calcite, brucite, and ACP in both systems (biotic and abiotic), the exact composition may still be different. The collected ACP in the biotic system might have a different structure compared to the ACP from the abiotic system, which might lead to a different stability of the amorphous phase. Preliminary leaching tests (Figure S4) indicate a higher $\mathrm{P}$ concentration in the bulk media $\left(1.28 \mathrm{mg} \mathrm{L}^{-1}\right)$ from the biotic precipitates than that of the abiotic precipitates $\left(0.294 \mathrm{mg} \mathrm{L}^{-1}\right)$ when the solids were mixed with deionized water. Furthermore, the presence of organic matters might also influence the stability of initial precipitates. ${ }^{38}$ These mechanisms might explain the dissolution of precipitates when the substrate concentration was not able to maintain the high local $\mathrm{pH}$. However, we do not have solid conclusions at this moment, and this interesting difference between abiotic and biotic systems calls for further investigation.

Phosphorus Removal at Increased Phosphate Concentration. As discussed earlier, the relative abundance of ACP in the precipitates was low. Calcite accounts for the largest proportion in the precipitates. This was probably due to the excess of bicarbonate in the wastewater $(10.1 \mathrm{mM}$ vs 0.23 $\mathrm{mM} \mathrm{P}$ ). In addition, the consumption of NaAc, as mentioned earlier, will add bicarbonate to the system. We previously showed in abiotic systems that a high concentration of phosphorus can enhance calcium phosphate precipitation and inhibit calcium carbonate precipitation. ${ }^{11}$ In order to investigate the performance of the bioelectrochemical system toward wastewaters with higher $\mathrm{P}$ content, we performed tests by spiking extra phosphate (in the form of $\mathrm{Na}_{2} \mathrm{HPO}_{4}$ ) to raise the $\mathrm{P}$ concentration to $0.76 \mathrm{mM}$.

The COD removal, the generation of current, and the removal efficiency of ions were similar to the case without spiking phosphorus (Table 1). However, the characterization of solids by XRD indicated that the relative contribution of components shifted. The XRD spectrum of solids collected in the presence of $0.76 \mathrm{mM} \mathrm{P}$ was dominated by a broad peak around $30^{\circ}$ (Figure S3) instead of a clear pattern for calcite (Figure 4A). The broad peak is typically seen for ACP. ${ }^{21,31}$ Similar to the case of $0.23 \mathrm{mM} \mathrm{P}$ (without spiking), the raw XRD pattern fails to identify the presence of brucite due to the small amount of brucite in the precipitates. When the solids were subjected to heating treatment, the new XRD pattern was dominated by hydroxyapatite (Figure S3), which supports the assumption that the initial form was mostly ACP. Figure 6 shows the relative abundance of ACP, calcite, and brucite in the solids obtained from the wastewater with $0.76 \mathrm{mM} \mathrm{P}$. In comparison to the wastewater with lower $\mathrm{P}$ concentration $(0.23 \mathrm{mM} \mathrm{P})$, the relative abundance of ACP increased from $21 \%$ to $66 \%$, whereas the relative abundance of calcite decreased from $73 \%$ to $24 \%$. Without supplying extra P, only $22 \%$ of the removed Ca formed precipitates with phosphate. At a concentration of $0.76 \mathrm{mM} \mathrm{P}, 73 \%$ of the removed Ca was used for ACP formation. This indicated that the increase of phosphate concentration reduced calcium carbonate formation in the bioelectrochemical system, which is in line with the results in the abiotic system. ${ }^{11}$

Thermodynamically, calcium phosphate species are less soluble than calcium carbonate, and in the wastewater, the precipitation of calcium phosphate has a higher driving force than calcium carbonate. ${ }^{11}$ However, in the wastewater, the $\mathrm{Ca} /$ $\mathrm{P}$ molar ratio was too high; therefore, there was $\mathrm{Ca}$ available for calcium carbonate formation. When extra phosphate was supplied, more Ca was used for ACP formation. While it is unrealistic to dose phosphate to the wastewater, there are other types of wastewater that contain high concentrations of phosphate, for instance, food wastewater. ${ }^{9}$ Therefore, it might be possible to produce high purity calcium phosphate 
from phosphorus-rich waste streams with bioelectrochemical phosphorus recovery process.

Energy Consumption. We found the bioelectrochemical system has good potential to recover phosphorus from waste streams at relatively low energy cost, depending on the phosphorus concentration, availability of substrate, and electrode material. The specific energy cost (as $\mathrm{kWh} / \mathrm{kg} \mathrm{P}$ ) increased with the added $\mathrm{NaAc}$ concentration. With $1.0 \mathrm{mM}$ $\mathrm{NaAc}$, although the $\mathrm{P}$ removal efficiency was relatively low ( $20 \%)$, the cell voltage was low as well, due to the low output current density. The low cell voltage compensates for the low $\mathrm{P}$ removal and results in the lowest energy consumption of $69 \pm$ $14 \mathrm{kWh} / \mathrm{kg} \mathrm{P}$ (Figure 7), with the regular cathode $(\mathrm{Ti})$ and

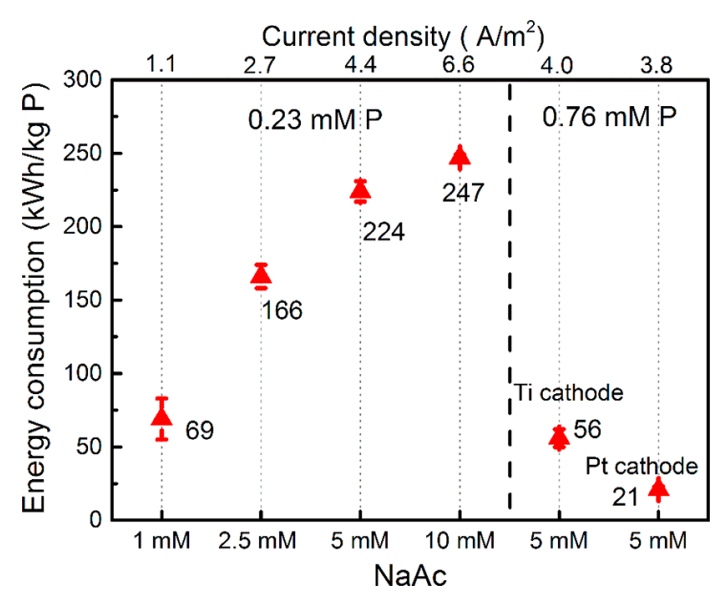

Figure 7. Specific energy consumption as a function of sodium acetate (NaAc) concentration, phosphorus concentration, and electrode material, expressed in $\mathrm{kWh}$ per $\mathrm{kg}$ phosphorus.

regular P concentration $(0.23 \mathrm{mM})$. This energy consumption was comparable to a fluidized bed cathode MEC that had a cathode and bioanode compartment separated by membranes, which was $65 \pm 5 \mathrm{kWh} / \mathrm{kg} \mathrm{P} .{ }^{19}$ In comparison to the single cell that was reported by Yuan and Kim, ${ }^{22}$ which had an energy consumption of $109 \mathrm{kWh} / \mathrm{kg} \mathrm{P}$ with the addition of $\mathrm{NaAc}$ (calculated from the reported $13.8 \mathrm{kWh} / \mathrm{kg}$ struvite), our energy consumption was relatively low. However, with increased $\mathrm{NaAc}$ concentration, the specific energy cost increased, reaching the highest $(247 \pm 2 \mathrm{kWh} / \mathrm{kg} \mathrm{P})$ at 10 $\mathrm{mM}$ NaAc. This suggests the increased current production was not matched by $P$ removal. ${ }^{19}$ It should be emphasized that the previous reported results produced struvite from phosphorusrich solutions $(1.5-4.5 \mathrm{mM} \mathrm{P}) .^{22,26}$ In our system, with $5 \mathrm{mM}$ $\mathrm{NaAc}$ and increased phosphorus concentration $(0.76 \mathrm{mM})$, the energy consumption dropped from $224 \pm 7$ to just $56 \pm 6$ $\mathrm{kWh} / \mathrm{kg} \mathrm{P}$. In principle, the energy input of the (bio)electrochemical system is affected by the internal resistance, the half reaction at working electrode, and the counter electrode. The use of a bioanode can reduce the minimum required cell voltage for hydrogen production, due to the lower equilibrium voltage of the bioelectrochemical system $(0.14 \mathrm{~V})$ compared to the electrochemical system $(1.23 \mathrm{~V}) .{ }^{15}$ The most energy intensive loss here, if we did not consider the ionic losses, is the overpotential of water reduction at the cathode. By using a Pt-coated Ti cathode, the average cell voltage was reduced from $1.56 \pm 0.05 \mathrm{~V}$ for the regular cathode (Ti plate) to $0.82 \pm 0.01 \mathrm{~V}$. Due to the decrease of cell voltage, the energy cost further decreased from $56 \pm 6 \mathrm{kWh} / \mathrm{kg} \mathrm{P}$ to $21 \pm 2$
$\mathrm{kWh} / \mathrm{kg} \mathrm{P}$. If we assume an electricity price of $0.09 € / \mathrm{kWh}$, the $\mathrm{P}$ recovery cost would be $1.92 \pm 0.21 € / \mathrm{kg}$ P. Such low cost would make this process very competitive, even compared to mined phosphorus, which lies in $1-2 € / \mathrm{kg} \mathrm{P} .^{39}$

Outlook. We demonstrated that phosphorus in domestic wastewater $(P=0.23 \mathrm{mM})$ and wastewaters with higher $P$ up to $0.76 \mathrm{mM}$ can be recovered as calcium phosphate in an energy efficient way by applying MEC. In line with the abiotic system, ACP, brucite, and calcite were formed as precipitates on the cathode surface. However, the removal of $\mathrm{Mg}$ was relatively low compared to the abiotic electrochemical system, since the current density obtained was much lower compared to the current density applied in the abiotic system. Therefore, the use of a bioelectrochemical system can reduce the formation of brucite. However, to reduce $\mathrm{CaCO}_{3}$ content in the solids, it is necessary to target a wastewater that has relative high phosphorus concentration. Both the purity and the energy consumption were substantially reduced at higher levels of phosphate, simulated by spiking $\mathrm{P}$ to the domestic wastewater. We found that the formed precipitates dissolved when the output current decreases, due to the depletion of substrate, while in the abiotic system they remained. Yet, we are unable to provide a clear explanation for this. We propose further research on understanding the difference between abiotic and biotic precipitates and avoiding the dissolution of initial precipitates.

\section{ASSOCIATED CONTENT}

\section{Supporting Information}

The Supporting Information is available free of charge on the ACS Publications website at DOI: 10.1021/acssuschemeng.9b00867.

COD information, XRD spectrum, leaching test, and wastewater composition (PDF)

\section{AUTHOR INFORMATION}

\section{Corresponding Author}

*E-mail: renata.vanderweijden@wur.nl.

ORCID $\odot$

Yang Lei: 0000-0003-0709-4743

Philipp Kuntke: 0000-0002-2342-8662

Notes

The authors declare no competing financial interest.

\section{ACKNOWLEDGMENTS}

This work was performed in the cooperation framework of Wetsus, European Centre of Excellence for Sustainable Water Technology (www.wetsus.eu). Wetsus is cofunded by the Dutch Ministry of Economic Affairs and Ministry of Infrastructure and Environment, the European Union Regional Development Fund, the Province of Fryslân, and the Northern Netherlands Provinces. This research has received funding from the European Union's Horizon 2020 research and innovation programme under the Marie Skłodowska-Curie Grant Agreement No. 665874. We are grateful to the participants of the research theme "Resource Recovery" for fruitful discussions and financial support.

\section{REFERENCES}

(1) Cordell, D.; Drangert, J.-O.; White, S. The Story of Phosphorus: Global Food Security and Food for Thought. Global Environmental Change 2009, 19 (2), 292-305. 
(2) Elser, J.; Bennett, E. Phosphorus Cycle: a Broken Biogeochemical Cycle. Nature 2011, 478 (7367), 29-31.

(3) Desmidt, E.; Ghyselbrecht, K.; Zhang, Y.; Pinoy, L.; Van der Bruggen, B.; Verstraete, W.; Rabaey, K.; Meesschaert, B. Global Phosphorus Scarcity and Full-scale P-recovery Techniques: a Review. Crit. Rev. Environ. Sci. Technol. 2015, 45 (4), 336-384.

(4) Mayer, B. K.; Baker, L. A.; Boyer, T. H.; Drechsel, P.; Gifford, M.; Hanjra, M. A.; Parameswaran, P.; Stoltzfus, J.; Westerhoff, P.; Rittmann, B. E. Total Value of Phosphorus Recovery. Environ. Sci. Technol. 2016, 50 (13), 6606-6620.

(5) Hao, X.; Wang, C.; van Loosdrecht, M. C.; Hu, Y. Looking Beyond Struvite for P-recovery. Environ. Sci. Technol. 2013, 47 (10), 4965-4966.

(6) Kappel, C.; Yasadi, K.; Temmink, H.; Metz, S. J.; Kemperman, A. J. B.; Nijmeijer, K.; Zwijnenburg, A.; Witkamp, G. J.; Rijnaarts, H. H. M. Electrochemical Phosphate Recovery from Nanofiltration Concentrates. Sep. Purif. Technol. 2013, 120, 437-444.

(7) Tran, A. T. K.; Zhang, Y.; De Corte, D.; Hannes, J.-B.; Ye, W.; Mondal, P.; Jullok, N.; Meesschaert, B.; Pinoy, L.; Van der Bruggen, B. P-recovery as Calcium Phosphate from Wastewater using an Integrated Selectrodialysis/crystallization Process. J. Cleaner Prod. 2014, 77, 140-151.

(8) Tervahauta, T.; van der Weijden, R. D.; Flemming, R. L.; Hernandez Leal, L.; Zeeman, G.; Buisman, C. J. Calcium Phosphate Granulation in Anaerobic Treatment of Black Water: a New Approach to Phosphorus Recovery. Water Res. 2014, 48, 632-642.

(9) Monballiu, A.; Ghyselbrecht, K.; Crabeels, X.; Meesschaert, B. Calcium Phosphate Precipitation in Nitrified Wastewater from the Potato-processing Industry. Environ. Technol. 2018, 1-17.

(10) Angel, R. Removal of Phosphate from Sewage as Amorphous Calcium Phosphate. Environ. Technol. 1999, 20 (7), 709-720.

(11) Lei, Y.; Remmers, J.; van der Weijden, R. D.; Saakes, M.; Buisman, C. J. Is There a Precipitation Sequence in Municipal Wastewater Induced by Electrolysis? Environ. Sci. Technol. 2018, 52 (15), 8399-8407.

(12) Venkatesan, A. K.; Hamdan, A. H.; Chavez, V. M.; Brown, J. D.; Halden, R. U. Mass Balance Model for Sustainable Phosphorus Recovery in a US Wastewater Treatment Plant. Journal of Environmental Quality 2016, 45 (1), 84-89.

(13) Rozendal, R. A.; Hamelers, H. V.; Rabaey, K.; Keller, J.; Buisman, C. J. Towards Practical Implementation of Bioelectrochemical Wastewater Treatment. Trends Biotechnol. 2008, 26 (8), 450459.

(14) Logan, B. E.; Hamelers, B.; Rozendal, R.; Schröder, U.; Keller, J.; Freguia, S.; Aelterman, P.; Verstraete, W.; Rabaey, K. Microbial Fuel Cells: Methodology and Technology. Environ. Sci. Technol. 2006, 40 (17), 5181-5192.

(15) Logan, B. E.; Call, D.; Cheng, S.; Hamelers, H. V.; Sleutels, T. H.; Jeremiasse, A. W.; Rozendal, R. A. Microbial Electrolysis Cells for High Yield Hydrogen Gas Production from Organic Matter. Environ. Sci. Technol. 2008, 42 (23), 8630-8640.

(16) Ichihashi, O.; Hirooka, K. Removal and Recovery of Phosphorus as Struvite from Swine Wastewater using Microbial Fuel Cell. Bioresour. Technol. 2012, 114, 303-307.

(17) Hirooka, K.; Ichihashi, O. Phosphorus Recovery from Artificial Wastewater by Microbial Fuel Cell and Its Effect on Power Generation. Bioresour. Technol. 2013, 137, 368-375.

(18) Cusick, R. D.; Logan, B. E. Phosphate Recovery as Struvite within a Single Chamber Microbial Electrolysis Cell. Bioresour. Technol. 2012, 107, 110-115.

(19) Cusick, R. D.; Ullery, M. L.; Dempsey, B. A.; Logan, B. E. Electrochemical Struvite Precipitation from Digestate with a Fluidized Bed Cathode Microbial Electrolysis Cell. Water Res. 2014, 54, 297306.

(20) Yuan, Y.; Zhou, S.; Tang, J. In Situ Investigation of Cathode and Local Biofilm Microenvironments Reveals Important Roles of $\mathrm{OH}-$ and Oxygen Transport in Microbial Fuel Cells. Environ. Sci. Technol. 2013, 47 (9), 4911-4917.
(21) Lei, Y.; Song, B.; van der Weijden, R. D.; Saakes, M.; Buisman, C. J. Electrochemical Induced Calcium Phosphate Precipitation: Importance of Local pH. Environ. Sci. Technol. 2017, 51 (19), 1115611164

(22) Yuan, P.; Kim, Y. Increasing Phosphorus Recovery from Dewatering Centrate in Microbial Electrolysis Cells. Biotechnol. Biofuels 2017, 10, 70.

(23) Lu, L.; Williams, N. B.; Turner, J. A.; Maness, P.-C.; Gu, J.; Ren, Z. J. Microbial Photoelectrosynthesis for Self-Sustaining Hydrogen Generation. Environ. Sci. Technol. 2017, 51 (22), 1349413501.

(24) Radjenovic, J.; Sedlak, D. L. Challenges and Opportunities for Electrochemical Processes as Next-Generation Technologies for the Treatment of Contaminated Water. Environ. Sci. Technol. 2015, 49 (19), 11292-11302.

(25) Jasper, J. T.; Yang, Y.; Hoffmann, M. R. Toxic Byproduct Formation during Electrochemical Treatment of Latrine Wastewater. Environ. Sci. Technol. 2017, 51 (12), 7111-7119.

(26) Li, W.-W.; Yu, H.-Q.; He, Z. Towards Sustainable Wastewater Treatment by Using Microbial Fuel Cells-Centered Technologies. Energy Environ. Sci. 2014, 7 (3), 911-924.

(27) Kelly, P. T.; He, Z. Nutrients Removal and Recovery in Bioelectrochemical Systems: a review. Bioresour. Technol. 2014, 153, $351-360$.

(28) Logan, B. E.; Rabaey, K. Conversion of Wastes into Bioelectricity and Chemicals by Using Microbial Electrochemical Technologies. Science 2012, 337 (6095), 686-690.

(29) Hovelmann, J.; Putnis, C. V. In Situ Nanoscale Imaging of Struvite Formation during the Dissolution of Natural Brucite: Implications for Phosphorus Recovery from Wastewaters. Environ. Sci. Technol. 2016, 50 (23), 13032-13041.

(30) Lei, Y.; Saakes, M.; van der Weijden, R. D.; Buisman, C. J. Effects of Current Density, Bicarbonate and Humic Acid on Electrochemical Induced Calcium Phosphate Precipitation. Chem. Eng. J. 2018, 342, 350-356.

(31) Lei, Y.; Song, B.; van der Weijden, R. D.; Saakes, M.; Buisman, C. J. Interaction of Calcium, Phosphorus and Natural Organic Matter in Electrochemical Recovery of Phosphate. Water Res. 2018, 142, 1017.

(32) Cid, C. m. A.; Jasper, J. T.; Hoffmann, M. R. Phosphate Recovery from Human Waste via the Formation of Hydroxyapatite during Electrochemical Wastewater Treatment. ACS Sustainable Chem. Eng. 2018, 6 (3), 3135-3142.

(33) Sleutels, T. H.; Molenaar, S. D.; Heijne, A. T.; Buisman, C. J. Low Substrate Loading Limits Methanogenesis and Leads to High Coulombic Efficiency in Bioelectrochemical Systems. Microorganisms 2016, 4 (1), 7

(34) Zehnder, A. J.; Huser, B. A.; Brock, T. D.; Wuhrmann, K. Characterization of an Acetate-decarboxylating, Non-hydrogenoxidizing Methane Bacterium. Arch. Microbiol. 1980, 124 (1), 1-11.

(35) Molenaar, S. D.; Mol, A. R.; Sleutels, T. H.; Ter Heijne, A.; Buisman, C. J. Microbial Rechargeable Battery: Energy Storage and Recovery through Acetate. Environ. Sci. Technol. Lett. 2016, 3 (4), 144-149.

(36) Sleutels, T. H.; Darus, L.; Hamelers, H. V.; Buisman, C. J. Effect of Operational Parameters on Coulombic Efficiency in Bioelectrochemical Systems. Bioresour. Technol. 2011, 102 (24), 11172-11176.

(37) Lei, Y.; Hidayat, I.; van der Weijden, R. D.; Saakes, M.; Buisman, C. J. Fate of Calcium, Magnesium and Inorganic Carbon in Electrochemical Phosphorus Recovery from Domestic Wastewater. Chem. Eng. J. 2019, 362, 453-459.

(38) Lin, Y.-P.; Singer, P. C.; Aiken, G. R. Inhibition of Calcite Precipitation by Natural Organic Material: Kinetics, Mechanism, and Thermodynamics. Environ. Sci. Technol. 2005, 39 (17), 6420-6428.

(39) Rock Phosphate Monthly Price, https://www.indexmundi. com/commodities/?commodity=rock-phosphate\&months $=12$, last accessed on April 17th, 2019. 